\title{
TRANSACTIONAL LEADERSHIP ON EMPLOYEE PERFORMANCE: JOB SATISFACTION AS A MODERATING VARIABLES
}

\author{
a Setiani, ${ }^{\mathrm{b}}$ Azhar Rizaldy \\ a,bUniversitas Islam Negeri Maulana Malik Ibrahim Malang \\ setiani@uin-malang.ac.id
}

\begin{tabular}{l|l|l} 
Received: October & Accepted : October & Published: December
\end{tabular}

\begin{abstract}
The purpose of this study is to see how transactional leadership affects employee performance using work satisfaction as a moderating variable. The methodologies used in this investigation are quantitative. The participants in this study were 100 employees of the Malang Regency's Kepanjen tax office. The sampling technique used a probability sampling technique with an accidental sampling approach. The sample used is 80 employees. Collecting data using questionnaires and interviews. Partially Least-Square Structural Equation Modelling (PLS-SEM) was utilized to analyze the data in this study. Transactional leadership has a good and significant effect on employee performance, according to the findings. Job satisfaction can moderate the impact of transactional leadership on employee performance at the Malang district tax service.
\end{abstract}

Keywords: employee performance; job satisfaction; transactional leadership.

\section{ABSTRAK}

Tujuan dari penelitian ini adalah untuk melihat bagaimana kepemimpinan transaksional mempengaruhi kinerja karyawan dengan menggunakan kepuasan kerja sebagai variabel moderasi. Metodologi yang digunakan dalam penelitian ini adalah kuantitatif. Partisipan dalam penelitian ini adalah 100 orang pegawai KPP Kepanjen Kabupaten Malang. Teknik pengambilan sampel menggunakan teknik probability sampling dengan pendekatan accidental sampling. Sampel yang digunakan adalah 80 karyawan. Pengumpulan data menggunakan kuesioner dan wawancara. Partially Least-Square Structural Equation Modeling (PLS-SEM) digunakan untuk menganalisis data dalam penelitian ini. Hasil penelitian yaitu kepemimpinan transaksional memiliki pengaruh positif dan signifikan terhadap kinerja karyawan; dan Kepuasan kerja dapat memoderasi pengaruh kepemimpinan transaksional terhadap kinerja pegawai pada Kantor Pelayanan Pajak Kabupaten Malang.

Kata Kunci: kinerja karyawan; kepuasan kerja; kepemimpinan transaksional.

\section{INTRODUCTION}

In the company's operational process, several factors can support a company to be more productive and advanced to achieve the company's goals. One of the factors is labor. In this situation, reaching the human resource goal plays a big part in every activity of an organization or company, regardless of its form, demonstrating that human resource management is the most crucial key that an organization or company may have. This is taken into account since it can impact the success or failure of the company's aims, one of which is employee performance. The organizational performance will always be a concern since, whatever the organization, performance is the key to its effectiveness and success (Mangkunegara, 2013). 
Factors that support the company to be advanced and make employees comfortable in the company are a leader who is carrying out his leadership function. This is because employees are comfortable when working and provide maximum results for the company according to the direction of their leadership. One of the causal factors that affect employee performance is the leadership factor (Indrasari, 2017). Leadership is the practice of inspiring people to desire to work toward common objectives (Griffin \& Ebert, 2015). Leadership is defined by a personality feature visible in a person's behavior when leading a group or organization (Wijono, 2018). According to (Robbins, 2010), the transactional leadership style is a leader who leads by using social exchanges (or transactions).

The transaction leader directs or motivates his subordinates to work toward goals by rewarding them for their productivity. Research (Karyono et al., 2019; Madjid \& Hidayanto, 2017) show that transactional leadership positively and significantly affects employee performance. This aligns with a study from (Oktora et al., 2017), which found that transactional leadership has a favorable and significant impact on employee performance. According to studies (Aqmarina \& Prasetya, 2016), transactional leadership does not influence employee performance.

Performance is an action that has been completed with the quality and quantity that employees have accomplished. According to (Kasmir, 2016), performance is the result of work and the behaviour of a person's work over a certain period can be measured by the ability to complete tasks and responsibilities. Job satisfaction is an individual thing because each individual will have a different level of satisfaction according to the values that apply to each individual. According to (Indrasari, 2017), job satisfaction is a condition of employee expression that is pleasant or unpleasant in their work. Job satisfaction reflects how people feel about their jobs. Several researchers have tested the relationship between job satisfaction and employee performance. Among them have a positive and significant effect carried out by (Aqmarina \& Prasetya, 2016). But research conducted by (Can, 2016) Job satisfaction has no significant adverse impact on employee performance.

In carrying out its functions when providing services in taxation, KPP Pratama Kepanjen applies Standard Operating Procedures (SOP); this should inspire employees to improve their performance. The values that become a reference for its employees include professionalism, synergy, service and perfection. Organizational restructuring at KPP Pratama Kepanjen by its leadership brought changes to the sustainability of its operations. Changes can be seen from the attitudes and behavior of employees when serving taxpayers, namely becoming more responsible for their work, the level of discipline increases because the system monitors it, the relationship between individuals is getting closer and upholds the employee code of ethics. Also, the efforts made to achieve organizational goals are more apparent and directed. Leadership at KPP Pratama Kepanjen must improve staff performance via a good organization. This is to create job satisfaction from employees in all units in the office. With the increase in job satisfaction of KPP Pratama Kepanjen, it is expected that there will also be an increase in employee performance to achieve the desired goals.

\section{THEORETICAL REVIEW}

Robbins and Judge (2015: 261), a leader who uses a transactional leadership style, directs or encourages their followers toward the goals established by outlining the responsibilities and tasks that must be completed. (Sendow \& Tatilu, 2014) Transactional leadership is a leader who needs to have clear information about what his subordinates need and want and must provide constructive feedback so that attendants stay on duty. Transactional leadership may include values, but these values are critical to the exchange process, such as honesty, accountability, and reciprocity. Transactional leaders help followers identify what to do; in their identification, leaders must consider the self-concept and self-esteem of their subordinates. Transactional leadership has a vital role in the company. From previous research (Aga, 2016; Hussain et al., 2017; Karyono et al., 2019; 
Misnawati, 2021; Oktora et al., 2017; et al., 2020; Yanthy et al., 2020), transactional leadership affects employee performance.

\section{$\mathbf{H}_{1}$ : Transactional Leadership With Performance Employee}

Job satisfaction refers to feelings or attitudes towards work, promotion opportunities, relationships with colleagues, supervision and satisfaction with the work itself (Indrasari, 2017). Explain that work satisfaction is a favourable feeling about what he performs based on the evaluation findings (Robbins \& Judge, 2015). Defines performance as the ability to complete tasks and obligations over some time, may utilize the capability to evaluate one's performance based on one's job and work behavior (Kasmir, 2016). According to (Utami et al., 2017), it shows that the variable job satisfaction moderates the relationship between leadership and employee performance. (Aqmarina \& Prasetya, 2016; Madjid \& Hidayanto, 2017; Mahdi, 2020), performed a similar study with the findings that job satisfaction moderation enhances the impact of leadership style on employee performance. This demonstrates that work happiness may enhance leadership's effect on employee performance.

$\mathbf{H}_{2}$ : Transactional Leadership on Performance Employees with Job Satisfaction as Moderating Variable

\section{METHODS}

The research approach used by the researcher uses quantitative research that emphasizes theoretical variables with numerical data and is analyzed. This measurement tool is in the form of a questionnaire, a questionnaire obtained from employees in the form of answers to questions asked submitted. The sort of research used by the researcher is explanatory research, and this is based on the previously specified research goals (Supriyanto \& Machfudz, 2010). Explanatory research tests the variables to be a hypothesis. Conducted this research at the Tax Office Pratama Kepanjen Jl. Raya Kepanjen Pakisaji, Jatirejoyoso, Kepanjen District, Malang Regency.

In this study, the population of employees at KPP Pratama Kepanjen is 100 employees. The sampling technique uses Simple Random Sampling, which is a way of taking samples from members of the population using random without regard to strata (levels) in the population members. As a result, the samples obtained can be considered representative; in this study, the determination of the number of samples is determined using the Slovin formula (Supriyanto \& Maharani, 2013) where:

$$
\begin{gathered}
n=\frac{N}{N \cdot e^{2}+1} \\
n=\frac{100}{100 \cdot(0.05)^{2}+1} \\
n=\frac{100}{1.25} \\
n=80
\end{gathered}
$$

According to the Slovin method, the researcher will take the required sample of 80 people from the results of the calculation of sampling.

The questionnaire is a data collection technique that gives a set of questions and written statements to be answered by respondents (Sugiyono, 2016). Then the interview, is a data collection technique if the researcher wants to conduct a preliminary study to determine the problems that must study (Sugiyono, 2016). The indicators used in this study are as follows: Transactional leadership (Pradana \& Fuadati, 2016): (1) Contingent rewards; (2) Management by exception active or active exception; (3) Management by passive exception or passive exception; (4) Laissez-faire. Next for Employee performance (Jatilaksono \& Indartono, 2016): (1) Working quantity; (2) Quality of work; (3) Time 
utilization; (4) Effectiveness; (5) Cooperation. Subsequent Job satisfaction (Luthans, 2006): (1) The work itself; (2) Income/salary; (3) Promotion opportunity; (4) Colleagues.

The measurement scale used in this study is a Likert scale. Answers from respondents are divided into five categories of assessment, namely: Strongly agree $=5$; Agree $=4$; Quite agree $=3$; Disagree $=2$; Strongly disagree $=1$.

Data analysis is an activity after data from all respondents is collected (Supriyanto \& Maharani, 2013). After that, the data is an analysis using partial least squares (PLS) software, namely smart PLS 3.0. The analytical approach employed in this study was partial linear square (PLS) analysis, which is a multivariate statistic that compares several dependent and independent variables. The partial linear square (PLS) analysis method is used for structural equation analysis based on variance, used together with structural model testing. The measurement model is used to test the validity and reliability, while the structural model is used to test causality (test hypotheses with predictive models) (Abdillah \& Hartono, 2015).

The moderation test is performed using the SmartPLS application and the bootstrapping procedure, looking at the $p$-value in the path coefficient; if the $p$-value for the moderating effect is less than 0.5 , the moderating variable can moderate the influence of the independent on the dependent variable. Suppose the moderating effect's p-value is more significant than 0.5 . In that case, the moderating variable cannot moderate the independent variable's influence on the dependent variable (Baron and Kenney, 1986 in Hartono and Abdillah, 2014).

\section{RESULT}

Testing the validity with convergent validity compares the AVE value of each latent variable with the correlation between the latent variable and other latent variables in the model used. The provision that the AVE value greater than 0.50 is considered valid (Chin, 1998). In this study, the validity test results were declared valid, meaning that the questionnaire in this study met convergent validity and can say that overall, the items built could accurately explain the variables. The results of the validity test are shown in Table 1 below:

Table 1

Convergent Validity Test Results

\begin{tabular}{llccc}
\hline \multicolumn{1}{c}{ Variable } & Item & $\begin{array}{c}\text { Factor } \\
\text { Loadi } \\
\text { ns }\end{array}$ & AVE & $\begin{array}{c}\text { Informatio } \\
\mathbf{n}\end{array}$ \\
\hline Transactional & KT1 & 0.757 & 0.524 & Valid \\
Leadership (KT) & KT2 & 0.653 & & \\
& KT3 & 0.841 & & \\
& KT4 & 0.562 & & \\
& KT5 & 0.570 & & \\
& KT6 & 0.779 & & \\
& KT7 & 0.743 & & \\
& KT8 & 0.783 & & \\
& KT9 & 0.738 & & \\
& KT10 & 0.761 & & \\
& & & & \\
Employee & K1 & 0.560 & 0.519 & \\
Performance $($ K $)$ & K2 & 0.618 & & \\
& K3 & 0.722 & & \\
& K4 & 0.650 & & \\
& K5 & 0.851 & & \\
& K6 & 0.773 & & \\
\hline
\end{tabular}




\begin{tabular}{|c|c|c|c|c|}
\hline & $\begin{array}{l}\text { K7 } \\
\text { K8 } \\
\text { K9 } \\
\text { K10 }\end{array}$ & $\begin{array}{l}0.733 \\
0.772 \\
0.684 \\
0.794\end{array}$ & & \\
\hline $\begin{array}{ll}\text { Job } & \text { Satisfaction } \\
\text { (KK) } & \end{array}$ & $\begin{array}{l}\text { KK1 } \\
\text { KK2 } \\
\text { KK3 } \\
\text { KK4 } \\
\text { KK5 } \\
\text { KK6 } \\
\text { KK7 } \\
\text { KK8 } \\
\text { KK9 } \\
\text { KK10 }\end{array}$ & $\begin{array}{l}0.746 \\
0.815 \\
0.854 \\
0.680 \\
0.786 \\
0.541 \\
0.569 \\
0.612 \\
0.780 \\
0.788\end{array}$ & 0.525 & Valid \\
\hline
\end{tabular}

\section{Data source: processed (2021)}

The reliability test results using internal consistency, namely Cronbach's Alpha (CA), another alternative besides CA that can use is Composite Reliability (CR). The recommended $\mathrm{CA}$ and $\mathrm{CR}$ values as benchmarks are 0.7 for exploratory research and above 0.8 for more advanced research (Malhotra, 1996).

\section{Table 2}

Values of CA and CR

\begin{tabular}{lcc}
\hline \multicolumn{1}{c}{ Variable } & $\begin{array}{c}\text { Cronbach's } \\
\text { Alpha (CA) }\end{array}$ & $\begin{array}{c}\text { Composite } \\
\text { Reliability }(\boldsymbol{C R})\end{array}$ \\
\hline Transactional Leadership & 0,898 & 0,916 \\
Job Satisfaction & 0,901 & 0,915 \\
Employee Performances & 0,897 & 0,914 \\
\hline Data source: processed (2021) & &
\end{tabular}

The results of Table 2 shows that the Cronbach's Alpha (CA) and Composite Reliability (CR) values are above 0.7 and even above 0.8 , so we can conclude that the questionnaire in this study meets the reliability criteria, which means that the indicators consistently and reliably represent the variables latently.

The measurement of this structural model is to examine the effect of transactional leadership, performance and job satisfaction. In this study, the R2 of employee performance was $58.5 \%$, meaning that transactional leadership had an influence of 58.5 per cent and the remaining 41.5 per cent was explained by other variables not included in this study. The table below illustrates this:

Table 3

Values of R Square

\begin{tabular}{lll}
\hline & $\boldsymbol{R}$ Square & $\boldsymbol{R}$ Square Adjusted \\
\hline Employee & 0.585 & 0.568 \\
Performances & & \\
\hline
\end{tabular}

Data source: processed (2021)

The results of hypothesis testing are in the form of images and values contained in the output path coefficients and indirect effects. Table 4, Table 5, and Figure 1 shows how it works. 
Table 4

Inner-Model Reflective Indicator Test Results

\begin{tabular}{|c|c|c|c|c|c|}
\hline $\begin{array}{l}\text { Correlation betwe } \\
\text { Variables }\end{array}$ & een & $\begin{array}{l}\text { Original } \\
\text { Sample } \\
\text { (O) }\end{array}$ & $\begin{array}{l}\text { T-Statistics } \\
(\mid \text { O/STDEV } \mid)\end{array}$ & P Values & $\begin{array}{l}\text { Hypothesis } \\
\text { Results }\end{array}$ \\
\hline $\begin{array}{l}\text { Transactional } \\
\text { Leadership } \\
\text { Employee } \\
\text { Performances }\end{array}$ & $\rightarrow$ & 0,681 & 9,342 & 0,000 & Accepted \\
\hline $\begin{array}{l}\text { Job Satisfaction } \\
\text { Employee } \\
\text { Performances }\end{array}$ & $->$ & 0,273 & 3,205 & 0,001 & Accepted \\
\hline
\end{tabular}

Data source: processed (2021)

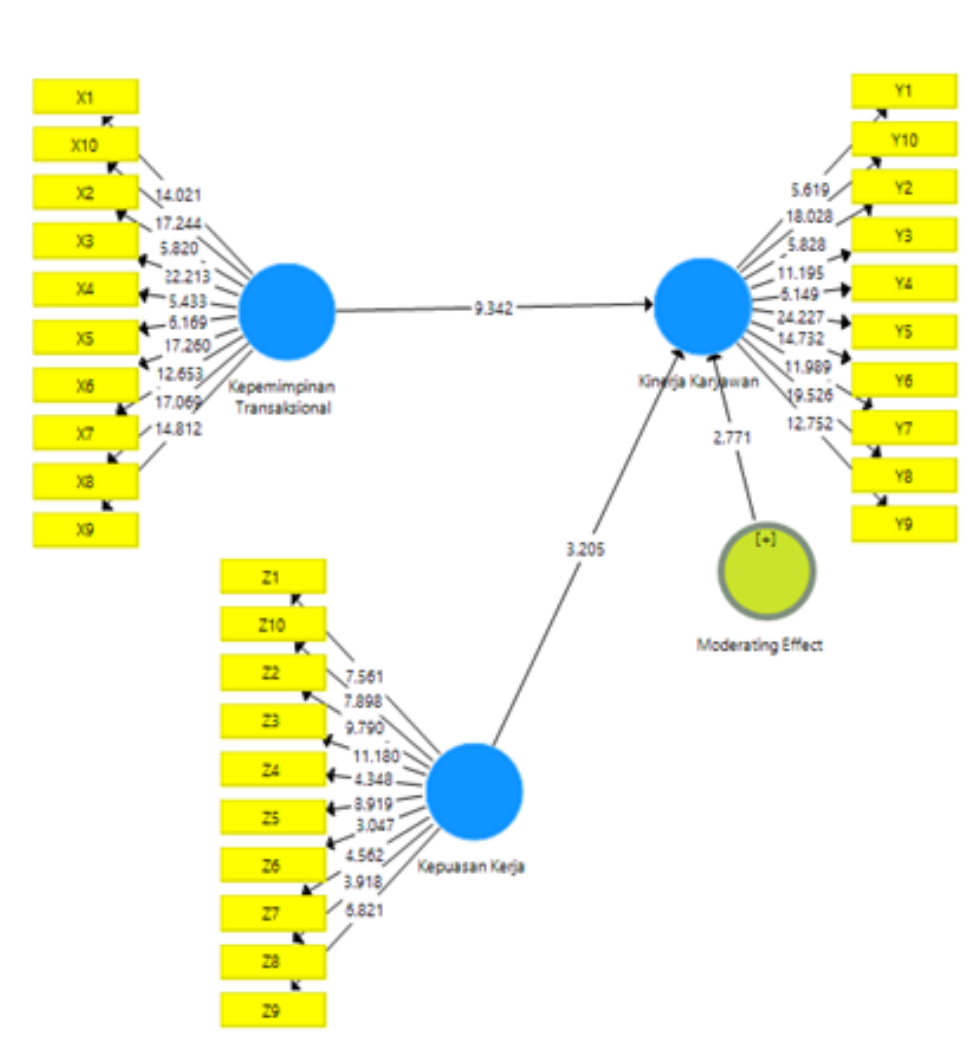

Figure 1. Hypothesis testing results

Table 5

Moderation Test Results

\begin{tabular}{lcccc}
\hline $\begin{array}{c}\text { Correlation between } \\
\text { Variables }\end{array}$ & $\begin{array}{c}\text { Original } \\
\text { Sample } \\
(\mathbf{O})\end{array}$ & $\begin{array}{c}\text { T Statistics } \\
(\mid \mathbf{O} / \text { STDEV } \mid)\end{array}$ & P Values & $\begin{array}{c}\text { Hypothesis } \\
\text { Results }\end{array}$ \\
\hline $\begin{array}{l}\text { Moderating effect }-> \\
\text { Employee }\end{array}$ & 0,233 & 2,771 & 0,006 & Accepted \\
Performances & & & & \\
\hline
\end{tabular}

Data source: processed (2021)

The inner model test in Table 4 indicates that all reflective indicators are significant since the p-value is less than $5 \%$. As a result, each latent variable's indicators accurately reflect the value of the other hidden variables. The influence of transactional leadership on employee performance is shown by the coefficient value of 0.681 , the $p$-value of 0.000 , and the t-statistic of 9.342 , according to the hypothesis test. The magnitude of the $p$-value is still 
below 0.5 , indicating that transactional leadership has a positive and significant effect on employee performance, so $\mathrm{H} 1$ is accepted.

Based on the hypothesis test in table 4, it is known that the moderating of job satisfaction on the effect of transactional leadership on employee performance is indicated by the coefficient value of $0.233, p$-value of 0.006 and t-statistic of 2.771 . The magnitude of the $p$-value is still below 0.5 , meaning that job satisfaction moderates the effect of transactional leadership on employee performance, so $\mathrm{H} 2$ is accepted.

The results of the Moderation Test are shown in table 5, and it can conclude that the moderating effect of job satisfaction from the influence of transactional leadership on employee performance obtains an original sample value of 0.233 and a $p$-value of $0.0006>0.5$.

\section{DISCUSSION}

Based on the results of the inner model, it is known that transactional leadership has a significant influence on employee performance. Therefore, the higher the transactional leadership, the higher the employee performance will be. On the other hand, if transactional leadership is low, the performance of employees will be lower. These results follow the conditions that occur in the Malang district tax service office that the leadership always provides feedback in the form of cash bonuses or goods when employees can work according to the goals desired by the administration. The head of the tax service office in the Malang district is always looking for precise information about what his subordinates need and want and then provide constructive feedback to stay on duty with enthusiasm (online interview).

The results of this study are following the theory put forward by Maurice in (Indrasari, 2017), which states that one of the causal factors that affect employee performance is the leadership factor. Leadership is the process of motivating others to want to work to achieve the goals that have been set (Griffin and Ebert, 2015). Leadership is based on a personality trait that may be noticed in a person's conduct when leading a group or organization (Wijono, 2018). According to (Robbins \& Coulter, 2010), the transactional leadership style is a leader who leads by using social exchanges (or transactions). The transaction leader directs or motivates his subordinates to work toward goals by rewarding them for their productivity. Research following this study's results is research (Aga, 2016; Hussain et al., 2017; Karyono et al., 2019; Misnawati, 2021; Oktora et al., 2017; et al., 2020; Yanthy et al., 2020), showing that transactional leadership positively and significantly affects employee performance.

Based on the results of the inner model, it is known that the moderating of job satisfaction on the effect of transactional leadership on employee performance. Indicating that job satisfaction can moderate the impact of transactional leadership on employee performance. The phenomenon that occurs in the tax service office, on average, gives a good performance. Employees' good performance is based on job satisfaction from employees when there is reciprocity/bonuses from the leadership. The pleasure shown by employees, such as when working, employees feel enjoy and do not have any pressure and then consistently perform well in a team. So that's what causes job satisfaction to strengthen the influence of transactional leadership on the performance of employees in the Malang district tax service office.

A successful company is a company that is able to satisfy its employees (Indrasari, 2017); when employees are satisfied, they tend to be happy in doing their jobs and not trying to evaluate other job alternatives. Employees with a high level of satisfaction with their work will feel more satisfied in other aspects of life to be sure to have better performance. Employees who experience job dissatisfaction will feel their work is a burden in itself. (Indrasari, 2017) suggests that job satisfaction refers to feelings or attitudes towards work, promotion opportunities, relationships with colleagues, supervision and satisfaction with the work itself. Research that is following the results of (Aqmarina \& Prasetya, 2016; Firmansah et al., 2018; Madjid \& Hidayanto, 2017; Mahdi, 2020; Widianto \& Supriyono, 2018) stated 
that job satisfaction was able to moderate the influence of leadership on employee performance.

\section{CONCLUSION}

Based on the results of research conducted, it is known that transactional leadership has a positive and significant influence on employee performance. This means that the Malang Regency Tax Service Office leader has influenced such as recognizing employees' achievements, actively taking corrective action after an action is taken, and giving employees the freedom to make decisions. If this is done well, then employee performance will also increase. Likewise, job satisfaction can moderate transactional leadership with employee performance, meaning that employee job satisfaction such as job challenges, salaries received, promotions and interactions between employees are well established. This can increase the influence of transactional leadership on employee performance.

\section{REFERENCES}

Aga, D. A. (2016). Transactional Leadership and Project Success: The Moderating Role of Goal Clarity. Procedia Computer Science, 100, 517-525. https://doi.org/10.1016/j.procs.2016.09.190

Abdillah, W., \& Hartono, J. (2015). Partial Least Square (PLS) Alternatif Structural Equation Modelling (SEM) dalam Penelitian Bisnis. Yogyakarta: Penerbit Andi

Aqmarina, N. S., \& Prasetya, H. N. U. A. (2016). Pengaruh Kepemimpinan Transformasional Dan Transaksional Terhadap Kepuasan Kerja Dan Kinerja Karyawan. Jurnal Administrasi Bisnis (JAB), 35(2), 164-173.

Can, A., \&Yasri, Y. (2016). Pengaruh Motivasi Kerja, KEpuasan Kerja dan Komitment Organisasi terhadap Kinerja Karyawan pada Bank Nagari. Jurnal Riset Manajemen dan Publik. Vol 4 No 1 Hal 1-26

Chin, W.W. (1998). The Partial Least Squares Approach for Structural Equation Modelling. Cleveland. Ohio

Firmansah, R., Supriyadi, E., \& . W. (2018). The Effect of Transactional Leadership and Organizational Culture to Employee Performance through Motivation of Employment. The International Journal of Social Sciences and Humanities Invention, 5(7), 48374841. https://doi.org/10.18535/ijsshi/v5i7.02

Griffin, Ricky W., \& Ebert, Ronald J. (2015). Pengantar Bisnis. Edisi kesepuluh. Jakarta: Penerbit Erlangga

Hussain, S. T., Abbas, J., Lei, S., Jamal Haider, M., \& Akram, T. (2017). Transactional leadership and organizational creativity: Examining the mediating role of knowledge sharing behavior. Cogent Business and Management, 4(1), 0-11. https://doi.org/10.1080/23311975.2017.1361663

Indrasari, M. (2017). Kepuasan Kerja dan Kinerja Karyawan Tinjauan dari Dimensi Iklim Organisasi , Kreatifitas Individu, dan Karakteristik Pekerjaan. Yogyakarta: Indomedia Pustaka, 1-85.

Jatilaksono, R.S., \& Indartono, S. (2016). Pengaruh Disiplin Kerja dan Budaya Organisasi terhadap Kinerja Karyawan. Jurnal Manajemen Bisnis Indonesia. Vol 5 No 6

Jufrizen, J., \& Lubis, A. S. P. (2020). Pengaruh Kepemimpinan Transformasional dan Kepemimpinan Transaksional terhadap Kinerja Pegawai Dengan Locus Of Control Sebagai Variabel Moderating. Maneggio: Jurnal IImiah Magister Manajemen, 3(1), 4159. https://doi.org/10.30596/maneggio.v3i1.4874

Karyono, Hidajat, T., \& Yuliana, R. (2019). Pengaruh Kepemimpinan Transaksional, Transformasional, Situasional, Visioner dan Pelayan Dengan Kinerja Pegawai 
Sekretariat DPRD Kabupaten Brebes. Jurnal Magisma, 7(2), 112-122.

Kasmir. (2016). Manajemen Sumber Daya Manusia (Teori dan Praktik). Depok: PT Raja Grafindo Persada

Luthans, Fred. (2006). Perilaku Organisasi. Edisi Kesepuluh. Yogyakarta: Penerbit Andi

Madjid, R., \& Hidayanto, T. (2017). Pengaruh Gaya Kepemimpinan dan Disiplin Kerja Terhadap Kinerja Karyawan Dengan Kepuasan Kerja Sebagai Variabel Moderating Pada PT. Prodia Widyahusada Cabang Sunter Jakarta. Media Manajemen Jasa, 4(1), 77-91.

Mahdi, Aiyub, Darmawati. (2020). Pengaruh gaya kepemimpinan transaksional dan transformasional terhadap kinerja guru dengan kepuasan kerja sebagai variabel intervening pada smk negeri di aceh utara. Jurnal Manajemen Indonesia, 5(2), 1-17.

Malhotra, N.K. (1996). Marketing Research An Applied. Oriented Second Edition. Practice Hall Inc. New Jersey

Mangkunegara, Anwar Prabu. (2013). Manajemen Sumber Daya Manusia Perusahaan. Bandung: Remaja Rosdakarya

Misnawati. (2021). Gaya Kepemimpinan Transaksional Dan Motivasi Terhadap Kinerja Karyawan Pt. Sinar Galesong Pratama Palu. Jurnal IImu Manajemen. Fakultas $\begin{array}{llll}\text { Ekonomi, } \quad \text { Universitas } & \text { Tadulako, 67-77. }\end{array}$ https://jimutuntad.com/index.php/jimut/article/view/219/215

Oktora, J., Rizan, M., \& Situngkir, S. (2017). Pengaruh Gaya Kepemimpinan Transaksional Dan Transformasional, Motivasi Serta Kompetensi Terhadap Kinerja Karyawan Pt. Sanjayatama Lestari. Jurnal Dinamika Manajemen Dan Bisnis, 1(1), 41-64. https://doi.org/10.21009/jdmb.01.1.2

Pradana, T., \& Fuadati, Siti R. (2016). Pengaruh Gaya Kepemimpinan Transaksional dan Budaya Organisasi terhadap Kinerja Karyawan. Jurnal Ilmu dan Riset Manajemen Vol 5 No 3. Hal 1-18

Robbins, Stephen P., \& Coulter, Mary. (2010). Manajemen Edisi kesepuluh. Jakarta: Penerbit Erlangga

Robbins, Stephen P., \& judge, T.A. (2015). Perilaku Organisasi. Jakarta: Salemba Empat

Sendow, G., \& Tatilu, J. (2014). Kepemimpinan Transaksional, Transformasional, Servant Leadership Pengaruhnya Terhadap Kinerja Karyawan Pada Pt. Sinar Galesong Pratama Manado. Jurnal Riset Ekonomi, Manajemen, Bisnis Dan Akuntansi, 2(1), 295304. https://doi.org/10.35794/emba.v2i1.3816

Sugiyono. (2016). Metode Penelitian Kuantitatif, Kualitatif, R\&D. Bandung: CV Alfabet

Supriyanto, Achmad S., \& Machfudz, Masyhuri. (2010). Metodologi Riset Manajemen Sumber Daya Manusia. Malang: UIN Maliki Press

Supriyanto, Achmad S., \& Maharani, Vivin. (2013). Metode Penelitian Manajemen Sumber Daya Manusia. Malang: UIN Maliki Press

Utami, A. B., Wibowo, E., \& Utami, S. S. (2017). Pengaruh kepemimpinan, budaya organisasi, dan profesionalisme terhadap kinerja dengan kepuasan kerja sebagai variabel moderasi. Jurnal Manajemen Sumber Daya Manusia, 11(1), 108-120.

Widianto, T., \& Supriyono, S. (2018). Pengaruh Kepemimpinan Dan Budaya Organisasi Terhadap Kinerja Karyawan Bank Syariah Dengan Kepuasan Kerja Sebagai Variabel Intervening. ProBank, 3(2), 52-59. https://doi.org/10.36587/probank.v3i2.379

Wijono, S. (2018). Kepemimpinan Dalam Perspektif Organisasi (p. 224). https://bpsdm.kemendagri.go.id/Assets/Uploads/laporan/73a40cf70d9761c41353a7d1a a6b5cdc.pdf

Yanthy, E., Purwanto, A., Pramono, R., Cahyono, Y., \& Asbari, M. (2020). Pengaruh Gaya Kepemimpinan Transformasional dan Tranksaksional Terhadap Kinerja Sistem Jaminan Halal HAS 23000. BISNIS: Jurnal Bisnis Dan Manajemen Islam, 8(1), 131153.

https://doi.org/10.21043/bisnis.v8i1.7045 